\title{
Dose conversion ratio for continuous intravenous infusion of fentanyl and fentanyl transdermal patches (reservoir-type)
}

\author{
Masakazu Kuroyama ${ }^{1,2)}$, Chihiro Kawano, 2), Takeshi Hirayama, ${ }^{1,2)}$, \\ Genki Iwasa $^{2)}$ and Toru Sasaki ${ }^{3)}$ \\ 1) Department of Pharmacy, Kitasato University East Hospital, 2) Pharmacy Practice and Science (Kitasato \\ University East Hospital), School of Pharmacy, Kitasato University, 3) Department of Gastroenterology, \\ Kitasato University School of Medicine
}

Recived 4/5/2012, revised 5/10/2012, accepted 6/4/2012

\begin{abstract}
Objectives: At present, the dose conversion ratio for a continuous intravenous infusion of fentanyl (CIV) and fentanyl transdermal patches (TP), which are widely used in Japan, is not based on the results of clinical studies in Japanese patients. Studies comparing serum fentanyl concentrations in patients with cancer pain treated by TP showed large differences between Japanese patients and those in other countries. We therefore studied the dose conversion ratio in Japanese patients. Methods: From October 2003 through October 2008, we extracted information on all patients with gastrointestinal cancer who underwent rotation from CIV to TP in the gastrointestinal ward of Kitasato University East Hospital. We selected patients in whom the daily dose of CIV or TP (i.e., the basic dose) was unchanged for 10 days after rotation and the difference in the number of rescue doses (per day) as compared with immediately before rotation was 1 or less on at least 3 consecutive days. All TP preparations used in this study were reservoir-type. Regression lines were plotted on the basis of the relation of "the basic released dose of TP" to "the basic prescribed dose of CIV," and the dose conversion ratio was calculated. Results: 47 patients underwent opioid rotation, and 11 of them satisfied the eligibility criteria. Eleven patients were studied. The following regression equation was obtained: $Y=1.0227 X+1.0103$, $r^{2}=0.9188$, indicating a strong correlation. The dose conversion ratio of CIV to TP (released dose) derived by regression analysis was 1:1. Conclusions: Our results obtained in Japanese patients will allow dose conversion at the time of opioid rotation from CIV to TP to be more appropriately performed.

Palliat Care Res 2012; 7(2): 218-24
\end{abstract}

Key words: cancer pain, opioid rotation, dose conversion ratio, continuous intravenous infusion of fentanyl, fentanyl patch

\section{Introduction}

The concept of "opioid rotation" has been advocated for the treatment of cancer pain and is defined as "switching from one opioid to another with the aim of achieving a better response." Actually, opioid rotation refers to changing the route of administration or switching to another opioid preparation because of uncontrollable side effects, inadequate analgesia even at an increased dose, inability to orally administer a preparation, or other factors ${ }^{11}$.

At the time of opioid rotation, changes in factors such as the type of opioid, dosage form, or route of administration necessitate dose adjustment to obtain an equivalent level of analgesic efficacy. It is therefore important to establish dose equivalency among different opioid preparations, and dose equivalency ratios for various prepara- tions have been reported ${ }^{2-8)}$.

On opioid rotation from continuous intravenous infusion of fentanyl (fentanyl CIV) to fentanyl transdermal patch (fentanyl TP), dose conversion can be based on the bioavailability of fentanyl TP because the active ingredient is the same. The interview forms for Durotep ${ }^{\circledR}$ patch, a fentanyl reservoirtype formulation of fentanyl TP, and Durotep ${ }^{\circledR}$ MT patch, a matrix formulation of fentanyl TP, state that the bioavailability is 0.92 . However, in the clinical study ( 8 patients) that was the source of this value, bioavailability widely ranged from 0.70 to 1.46 and exceeded 1.0 in 2 patients ${ }^{9}$. These findings suggested that the bioavailability in that clinical study might have been overestimated owing to some factor(s). Therefore, it may not be appropriate to directly use the bioavailability obtained in that study for dose conversion.

\footnotetext{
Corresponding author: Masakazu Kuroyama Department of Pharmacy, Kitasato University East Hospital

2-1-1 Asamizodai, Minami-ku, Sagamihara-shi, Kanagawa, 252-0380 Japan

TEL 042-748-9111 FAX 042-746-8906 E-mail: kuroyama@kitasato-u.ac.jp
} 
In clinical practice, a dose conversion ratio of 1:1 has been used for switching from fentanyl CIV to fentanyl TP on the basis of the results of a study conducted by Grond, et $\mathrm{a}^{100}$. However, this ratio was not derived from the results of clinical studies in Japanese patients. The summary basis of approval for Durotep ${ }^{\circledast}$ patch $^{11)}$ reported substantial differences in serum fentanyl concentrations between Japanese patients with cancer pain and patients with cancer pain in other countries. To our knowledge, dose conversion ratios for fentanyl CIV and fentanyl TP have not been clinically studied previously in Japanese patients. We therefore examined dose conversion ratios in Japanese patients with cancer pain who underwent opioid rotation from fentanyl CIV to fentanyl TP.

\section{Methods}

\section{Patients}

From October 2003 through October 2008, we extracted data on all patients with gastrointestinal cancer who underwent opioid rotation from fentanyl CIV to fentanyl TP at the gastrointestinal disease ward of Kitasato University East Hospital. According to the method by Kawano, et $\mathrm{al}^{2,3)}$, we selected patients in whom the daily dose of fentanyl CIV or fentanyl TP (i.e., the basic dose) was unchanged for 10 days after rotation and the difference in the number of rescue doses (per day) as compared with immediately before rotation was 1 or less on at least 3 consecutive days. All fentanyl TP preparations used in our study were reservoirtype. Our study was performed after approval had been obtained from the Ethics Review Board of Kitasato University Hospital.

\section{Variables}

The following information was obtained from the patients' medical records: basic demographic information (sex, age, height, body weight, and diagnosis), serum chemical values related to hepatic and renal function immediately before opioid rotation (total protein, serum albumin, total bilirubin, direct bilirubin, aspartate aminotransferase levels [AST], alanine aminotransferase [ALT], blood urea nitrogen [BUN], serum creatinine, and creatinine clearance), and the reasons for performing opioid rotation.

As for the use of opioids, the basic doses and the numbers of rescue doses (per day) of fentanyl CIV and fentanyl TP were surveyed from immediately before rotation until 10 days after rotation. Given that $2.5 \mathrm{mg} / 3$ days of reservoir-type fentanyl TP is equivalent to a released dose of $0.6 \mathrm{mg} /$ day of fentanyl ${ }^{12)}$, the daily released dose (basic released dose) was calculated from the basic prescribed dose of fentanyl TP.

\section{Methods for calculation of dose conversion ratios}

Dose conversion ratios were calculated by regression line analysis of the relation of "the basic released dose of fentanyl TP to the basic prescribed dose of fentanyl CIV." Statistical analysis was performed using the SPSS ${ }^{\circledR} 18.0 \mathrm{~J}$ for software package for Windows ${ }^{\circledR}$.

\section{Results}

During the study period, 47 patients underwent opioid rotation from fentanyl CIV to fentanyl TP. In 11 of these patients, the basic dose of fentanyl CIV or fentanyl TP was unchanged for 10 days after opioid rotation and the difference in the daily number of rescue doses was 1 or less on at least 3 consecutive days as compared with immediately before rotation. Reservoir-type Durotep ${ }^{\circledR}$ fentanyl patches were used as fentanyl TP in all patients. The patients' demographic characteristics are shown in Table 1. Table 2 shows the serum chemical values immediately before opioid rotation.

In the 11 selected patients, the median basic prescribed dose of fentanyl CIV was $0.5 \mathrm{mg}$ (range, 0.4 to 2.4 ), and the median basic released dose of fentanyl TP was $0.6 \mathrm{mg}$ (range, 0.3 to 2.4). Fig. 1 shows the relation between the basic prescribed dose of fentanyl CIV and the basic released dose of fentanyl TP in the subjects. The following regression equation was obtained: $\mathrm{Y}=1.0227 \mathrm{X}+0.0103, \mathrm{r}^{2}=$ 0.9188 , indicating a strong correlation. This regression equation indicated that the dose conversion ratio for fentanyl CIV and fentanyl TP (released dose) was 1:1.

\section{Discussion}

Fentanyl is a potent opioid with high affinity for the $\mu_{1}$-opioid receptor and low affinity for the $\mu_{2}$-opioid receptor. It is about 100 times more potent than morphine. As compared with morphine and oxycodone, fentanyl is associated with lower incidences of side effects such as constipation, vomiting, and drowsiness ${ }^{4}$. Moreover, the main metabolite of fentanyl, norfentanyl, has virtually no pharmacologic activity and thus does not augment pharmacologic effects in patients with decreased renal function, in contrast to morphine-6-glucuronide, a metabolite of morphine. Fentanyl can be therefore easy to use in patients with compromised renal function ${ }^{13,14}$. Fentanyl has a low molecular weight and is highly lipophilic, allowing it to be delivered by a transdermal patch. Fentanyl TP is superior to other opioid preparations because it is simple and noninvasive, with a long duration of action $^{12,15)}$. Because many patients with terminal cancer have difficulty in oral intake, fentanyl TP offers substantial advantages ${ }^{16}$. Owing to these characteristics, fentanyl TP plays a very important role in clinical practice. We thus consider it very meaningful to study opioid rotation from fentanyl CIV to fentanyl TP and thereby promote the appropriate use of these preparations.

In our study, the dose conversion ratio was based on response within the first 10 days after opioid rotation. Patients who had increased pain intensity caused by exacerbation of underlying disease were therefore excluded. In addition, the dose conversion ratio was calculated on the basis of data from patients in whom the basic prescribed dose was unchanged and the difference in the number of rescue doses (per day) as compared with immediately before rotation was 1 or less on at least 3 consecutive days.

Fentanyl injection was most commonly used to supply rescue doses, followed by oral solution and suppositories of morphine hydrochloride and oxycodone hydrochloride powder. If fentanyl CIV was used as the basic prescribed drug, fentanyl was given as a rapid intra- 
Table 1 Demographic Characteristics of Patients

\begin{tabular}{|c|c|c|}
\hline Sex (male:female) & $7: 4$ & \\
\hline Age [Median (Range)] years & $65(35-77)$ & \\
\hline Height [Median (Range) ] cm & $159.2(149.0-178.2)$ & \\
\hline Body weight [Median (Range)] kg & $59.2(39.0-74.7)$ & \\
\hline \multirow[t]{5}{*}{ Diagnosis } & Gastric cancer & 4 \\
\hline & Pancreatic cancer & 3 \\
\hline & Bile-duct cancer & 2 \\
\hline & Colorectal cancer & 1 \\
\hline & Liver cancer & 1 \\
\hline \multirow[t]{3}{*}{ Concomitant analgesics } & NSAIDs * (oral) & 1 \\
\hline & NSAIDs (injection) & 1 \\
\hline & Acetaminophen & 1 \\
\hline \multirow[t]{6}{*}{ Reasons for performing opioid rotation } & Staying out overnight and discharge from the hospital & 5 \\
\hline & Pain control & 2 \\
\hline & Detailed dose management & 1 \\
\hline & More stable serum concentrations & 1 \\
\hline & Reduction in side effects & 1 \\
\hline & Water restriction & 1 \\
\hline
\end{tabular}

NSAIDs; nonsteroidal anti-inflammatory drugs.

Table 2 Serum Chemical Values (Values immediately before opioid rotation)

\begin{tabular}{l|cc}
\hline & Median value & Range \\
\hline Total protein $(\mathrm{g} / \mathrm{d} /)$ & 6.2 & $4.2-7.1$ \\
Serum albumin $(\mathrm{g} / \mathrm{d} /)$ & 2.9 & $1.6-4$ \\
Total bilirubin $(\mathrm{mg} / \mathrm{d} /)$ & 1.2 & $0.4-4$ \\
Direct bilirubin $(\mathrm{mg} / \mathrm{d} /)$ & 0.8 & $0.1-0.3$ \\
AST $(\mathrm{U} / \mathrm{l})$ & 28 & $16-135$ \\
ALT $(\mathrm{U} / \mathrm{l})$ & 25 & $15-103$ \\
Blood urea nitrogen $(\mathrm{mg} / \mathrm{d} /)$ & 27 & $8-40$ \\
Serum creatinine $(\mathrm{mg} / \mathrm{d} /)$ & 0.75 & $0.37-4.14$ \\
Creatinine clearance $(\mathrm{m} / / \mathrm{min})$ & 81 & $13.7-119.5$ \\
\hline
\end{tabular}

Creatinine clearance was estimated with the Cockcroft-Gault equation.

AST; aspartate aminotransferase, ALT; alanine aminotransferase.

venous infusion at a dose equivalent to $1 / 24$ to $1 / 12$ of the basic prescribed dose for rescue treatment. If fentanyl TP was used as the basic prescribed drug, fentanyl was given orally or in suppository form in a dose equivalent to $1 / 6$ to $1 / 4$ of the basic prescribed dose (released dose) or by intravenous injection in a dose equivalent to $1 / 12$ to $1 / 6$ of the basic prescribed dose (released dose). In our hospital, rescue doses are prescribed at the same time as basic prescribed drugs, and patients can take rescue doses any time they feel pain. All subjects in our study were prescribed rescue doses. Therefore, the use of rescue doses is considered a clinical indicator that most strongly reflects pain experienced by the patient. The use of rescue doses in patients with a low basic prescribed dose may be reflected in the basic prescribed dose on the next day (i.e., as a dose increase). A high basic prescribed dose often leads to side effects such as drowsiness, leading to modification of (i.e., a decrease in) the basic prescribed dose from the next day.

Eleven patients who met the protocol requirements were selected for this study. The regression equation indicating the relation between the basic prescribed dose $(\mathrm{X})$ of fentanyl CIV and basic released dose (Y) of fentanyl TP was $\mathrm{Y}=1.0227 \mathrm{X}+0.0103, \mathrm{r}^{2}=0.9582$, indicating a strong very correlation. The dose conversion ratio derived from the regression equation was 1:1 for switching from fentanyl CIV to fentanyl TP, which was similar to the ratio widely used in clinical practice. 


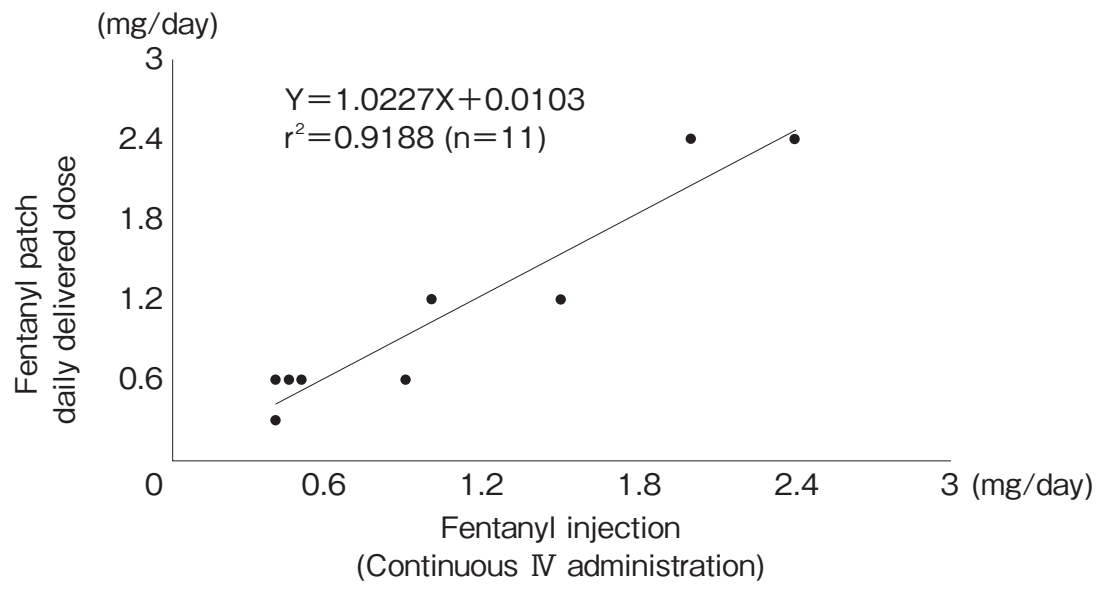

Fig. 1 Relation between daily dose (basic prescribed dose) of fentanyl CIV and daily released dose (basic released doses) of fentanyl TP

The concurrent use of nonopioid analgesics may augment analgesic effects, decreasing the required dose of opioids ${ }^{17}$. Nine of our 11 patients concurrently used analgesics other than opioids. All patients had continuously received these analgesics from before the start of opioid rotation, and the drugs and dosage used were not altered. The effect of concomitant analgesics on the dose conversion ratio calculated in our study was thus considered minimal.

Of the 11 subjects, 3 had grade 3 abnormalities on serum blood chemical analysis as defined by Common Terminology Criteria for Adverse Events (CTCAE), version 4: abnormal serum albumin levels in 1 patient, abnormal total bilirubin levels in 1, and abnormal serum creatinine levels in 1. Serum levels of free fentanyl and drug effectiveness are increased by decreased hepatic blood flow, hepatic intrinsic clearance, and serum albumin levels, but are unaffected by renal function ${ }^{18,19}$. However, because fentanyl TP, a transdermal patch, is not affected by the first pass effect in the liver, the pharmacokinetics of fentanyl TP are considered similar to those of fentanyl CIV. Therefore, fluctuations in serum chemical values immediately before opioid rotation are considered to have a minimal effect on the dose conversion ratio for fentanyl CIV and fentanyl TP. After excluding the 3 patients who had grade 3 abnormalities on serum chemical testing according to CTCAE, version 4 , the relation between the basic prescribed dose of fentanyl CIV and the basic released dose of fentanyl TP was assessed in 8 patients, and the following regression equation was obtained: $\mathrm{Y}=1.0634 \mathrm{X}+0.0075, \mathrm{r}^{2}=0.9063$, indicating a strong correlation and no effect on the dose conversion ratio.

All fentanyl TP preparations used in our study were reservoir-type. A comparative study of the pharmacokinetic parameters calculated on the basis of serum fentanyl concentrations after treatment with reservoir-type and matrix-type preparations showed that these two preparations are bioequivalent ${ }^{20}$. We therefore believe that the dose conversion ratio obtained in our study can be used for matrix-type preparations.

The dose conversion ratio for opioid rotation from fentanyl CIV to fentanyl TP currently used in Japan is based on the results of a study conducted by Grond, et $\mathrm{al}^{10)}$. Their study did not include Japanese patients. The summary basis of approval of Durotep ${ }^{\circledR}$ patch $^{11)}$ reported a large difference in serum fentanyl concentrations between Japanese patients with cancer pain and those from other countries. Our study clarified the dose conversion ratio for opioid rotation from fentanyl CIV to fentanyl TP in Japanese patients with cancer pain. On the basis of Japanese data, dose conversion at the time of opioid rotation from fentanyl CIV to fentanyl TP can be appropriately performed, contributing to improvement in patients' quality of life.

Because our study was retrospective, pain intensity at the time of using rescue doses was not examined. As mentioned above, rescue doses are prescribed at the same time as basic prescribed drugs in our hospital, and patients can take rescue doses whenever they feel pain. Therefore, the number of rescue doses used is considered a clinical index that most closely reflects patients' pain. Future studies should further assess pain intensity before and after opioid rotation, as well as the types and numbers of rescue doses used.

\section{References}

1) Mercadante S. Opioid rotation for cancer pain: rationale and clinical aspects. Cancer 1999; 86: 1856-66.

2) Kawano C, Hirayama T, Kuroyama M. Dose conversion in opioid rotation from continuous intravenous infusion of morphine hydrochloride injection to fentanyl patch in the management of cancer pain. Yakugaku Zasshi 2011; 131: 463-7.

3) Kawano C, Hirayama T, Sasaki T, et al. Dose Conversion during opioid rotation from continuous intravenous infusion of morphine hydrochloride to oral administration of oxycodone sustainedrelease tablets. Jpn J Pharm Health Care Sci 2012; 38: 170-6.

4) Ogawa J, Nakamura K, Iizuka K, et al. Optimal conversion ratio of oral morphine to transdermal fentanyl patches to the cancer pain. Yakugaku Zasshi 2009; 129: 335-40.

5) Kato K, Mizaki T, Yamazaki S, et al. A study of transdermal fentanyl in cancer pain at Aichi-Cancer Center. Yakugaku Zasshi 2004; 124: 287-91.

6) Pereira J, Lawlor P, Vigano A, et al. Equianalgesic dose ratios for opioids: a critical review and proposals for long-term dosing. J Pain Symptom Manage 2001; 22: 672-87.

7) Moryl N, Santiago-Palma J, Kornick C, et al. Pitfalls of opioid 
rotation: substituting another opioid for methadone in patients with cancer pain. Pain 2002; 96: 325-8.

8) Tse DM, Sham MM, Ng DK, et al. An ad libitum schedule for conversion of morphine to methadone in advanced cancer patients: an open uncontrolled prospective study in a Chinese population. Palliat Med 2003; 17: 206-11.

9) Varvel JR, Shafer SL, Hwang SS, et al. Absorption characteristics of transdermally administered fentanyl. Anesthesiology 1989; 70: 928-34.

10) Grond S, Zech D, Lehmann KA, et al. Transdermal fentanyl in the long-term treatment of cancer pain: a prospective study of 50 patients with advanced cancer of the gastrointestinal tract or the head and neck region. Pain 1997; 69: 191-8.

11) Summary Basis of Appoval; Durotep patch. cited 5 August, 2011 〔http://www.info.pmda.go.jp/shinyaku/P200700062/ 80015500_22000AMX042_A100_1.pdf]

12) Interview form of Durotep ${ }^{\circledR}$ patch. JANSSEN PHARMACEUTICAL K.K, 2003.

13) Walter C, Felden L, Lötsch J. Bioequivalence criteria for transdermal fentanyl generics: do these need a relook? Clin Pharmacokinet $2009 ; 48: 625-33$.

14) Mercadante $S$. The role of morphine glucuronides in cancer pain.
Palliat Med 1999; 13: 95-104.

15) Schneider E, Brune K. Opioid activity and distribution of fentanyl metabolites. Naunyn Schmiedebergs Arch Pharmacol 1986; 334: 267-74.

16) Payne R.Transdermal fentanyl: suggested recommendations for clinical use. J Pain Symptom Manage 1992; 7 (Suppl 3): S404.

17) Mercadante S, Fulfaro F, Casuccio A. A randomised controlled study on the use of anti-inflammatory drugs in patients with cancer pain on morphine therapy: effects on dose-escalation and a pharmacoeconomic analysis. Eur J Cancer 2002; 38: 1358-63.

18) McClain DA, Hug CC Jr. Intravenous fentanyl kinetics. Clin Pharmacol Ther 1980; 28: 106-14.

19) Meuldermans WE, Hurkmans RM, Heykants JJ. Plasma protein binding of fentanyl, sufentanil, alfentanil and lofentanil in blood. Arch Int Pharmacodyn Ther 1982; 257: 4-19 .

20) Summary Basis of Appoval; Durotep ${ }^{\circledR}$ patch MT. cited 25 April, 2011 〔http://www.info.pmda.go.jp/shinyaku/P200700062/ 800155000_22000AMX01422_A100_1.pdf]

Potential conflicts of interest; The author(s) indicated no potential conflicts interest. 


\section{原著}

\section{フェンタニル注射剤持続静脈内投与と貼付剤 (リザーバー型) の投与量換算比に関する研究}

黒山 政一 ${ }^{1,2)}$, 川野 千尋 ${ }^{1,2)}$, 平山 武司 ${ }^{1,2)}$, 岩佐 元輝 ${ }^{2)}$, 佐々木 徹 ${ }^{3)}$

1) 北里大学東病院 薬骫部, 2) 北里大学 薬学部 薬物治療学 II, 3) 北里大学 医学部 消化器内科学

【目的】現在, わが国におけるフェンタニルの持続静脈内投与 (CIV) と貼付剂 (TP) との換算比は, 日本人のデータに基づく ものではない. TP の日本人と外国人の血中濃度では大きな差がある. そこで, 日本人を対象に換算比の検討を行った. 【方 法】2003 年から 2008 年に北里大学東病院で, CIV と TP のローテーション (RO) が施行されたすべての消化器がん患者 を抽出. $\mathrm{RO}$ 施行後 10 日以内に, 1 日あたりの投与量 (基本量) が不変, かつレスキュー回数 (1 日あたり) の差が RO 直前と 比べ 1 回以内である状態を 3 日間連続した患者を選択. TP はすべてリザーバー型. “CIV 基本量”と“TP 基本量”の回帰直線 から換算比を算出.【結果】 47 症例に $R O$ が実施され, 11 症例を選択. 回帰式は $Y=1.0227 X+0.0103, r^{2}=09188$. 換算 比は CIV: TP(放出量)=1: 1. 【考察】日本人のデータに基づいた CIV と TP 換算が可能となった.

Palliat Care Res 2012; 7(2): 218-24

Key words: がん疼痛, オピオイドローテーション, 投与量換算比, フェンタニル注射剂持続静注, フェンタニル貼付剤

\begin{tabular}{|c|c|c|}
\hline 性別 (男/女) & \multicolumn{2}{|l|}{$7 / 4$} \\
\hline 年齢〔中央値 (範囲)〕歳 & \multicolumn{2}{|l|}{$65(35-77)$} \\
\hline 身長〔中央值 (範囲) $] \mathrm{cm}$ & \multicolumn{2}{|l|}{$159.2(149.0-178.2)$} \\
\hline 体重〔中央値 (範囲)〕 kg & \multicolumn{2}{|l|}{$59.2(39.0-74.7)$} \\
\hline \multirow[t]{5}{*}{ 診断名 } & 胃がん & 4 \\
\hline & 膵臓がん & 3 \\
\hline & 胆管がん & 2 \\
\hline & 大腸がん & 1 \\
\hline & 肝臓がん & 1 \\
\hline \multirow[t]{3}{*}{ 併用鎮痛薬 } & NSAIDs (経口) & 1 \\
\hline & NSAIDs (注射) & 1 \\
\hline & アセトアミノフェン & 1 \\
\hline \multirow[t]{6}{*}{ オピオイドローテーションの理由 } & 外泊・退院のため & 5 \\
\hline & ペインコントロールがついたため & 2 \\
\hline & 詳細な投与量管理を行うため & 1 \\
\hline & より安定した血中濃度を得るため & 1 \\
\hline & 副作用の軽減のため & 1 \\
\hline & 水分量制限のため & 1 \\
\hline
\end{tabular}


表 2 生化学的検査值 (オピオイドローテーション直前值)

\begin{tabular}{l|cc}
\hline & 中央值 & 範囲 \\
\hline 総タンパク $(\mathrm{g} / \mathrm{d} /)$ & 6.2 & $4.2-7.1$ \\
血清アルブミン $(\mathrm{g} / \mathrm{d} /)$ & 2.9 & $1.6-4$ \\
総ビリルビン $(\mathrm{mg} / \mathrm{d} /)$ & 1.2 & $0.4-4$ \\
直接ビリルビン $(\mathrm{mg} / \mathrm{d} /)$ & 0.8 & $0.1-0.3$ \\
$\mathrm{AST}(\mathrm{U} / \mathrm{l})$ & 28 & $16-135$ \\
$\mathrm{ALT}(\mathrm{U} / \mathrm{l})$ & 25 & $15-103$ \\
尿素窒素 $(\mathrm{mg} / \mathrm{d} /)$ & 27 & $8-40$ \\
血清クレアチニン $(\mathrm{mg} / \mathrm{d} /)$ & 0.75 & $0.37-4.14$ \\
クレアチニンクリアランス $(\mathrm{m} / /$ 分) & 81 & $13.7-119.5$ \\
\hline \multicolumn{2}{c}{ クレアチニンクリアランスは cockcroft-gault 式より算出 }
\end{tabular}

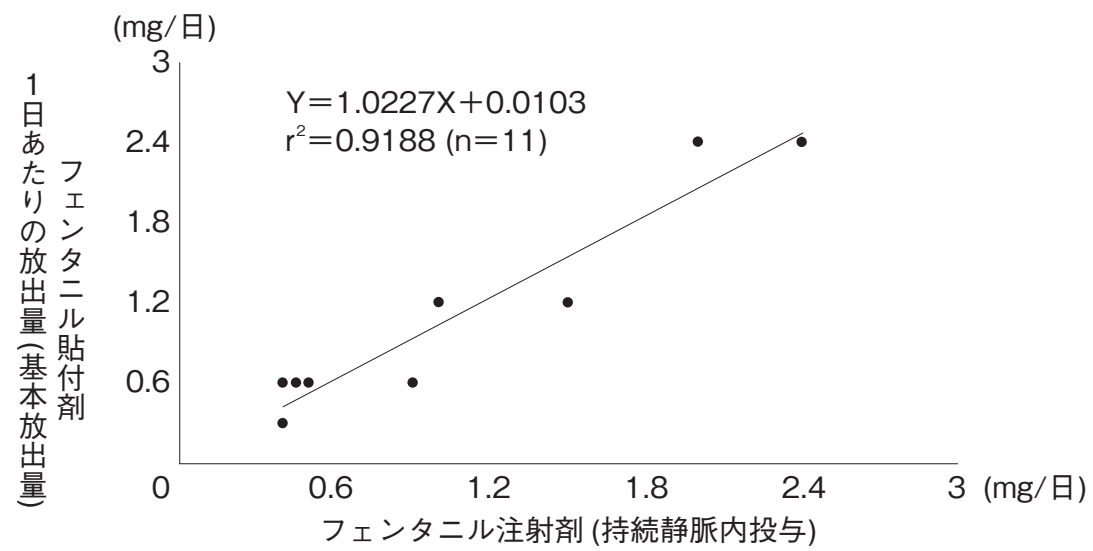

図 1 フェンタニル注射剂 (CIV) の 1 日あたりの投与量 (基本処方量) とフェンタ ニル貼付剂 (TP)の1 日あたりの放出量 (基本放出量)の相関関係 